\title{
The Biology, Ecology and Medicine Faculty of Dnipropetrovsk National University after Oles' Gonchar
}

\author{
Olexandr Pakhomov \\ Department of Zoology and Ecology, Biology, Ecology and Medicine Faculty, Dnepropetrovsk National University, \\ Gagarina av., 72, 49010 Dnepropetrovsk. Ukraine, e-mail: didur@ua.fm
}

Keywords: Biology faculty, education, university, speciality, Research Institute of Biology

\author{
SUMMARY
}

The historical rewiev of Biology, Ecology and Medicine Faculty is presented. The Faculty of Biology, Ecology and Medicine has 7 Departments, Aquarium complex, Zoological Museum, Vivarium and Herbarium. It works in cooperation with the Research Institute of Biology, Botanical Garden, O. L. Bel'gard International Biosphere Station, and Biological Station of DNU and forms the regional Centre of Science, Education and Culture in the field of Biology, Ecology and Nature Conservation in Central Ukraine. The Faculty proposes courses in the following specialities: Biology, Zoology, Botany, Microbiology and Virology, Biochemistry, Physiology, Ecology, Environmental Protection and Balanced Nature Management. All of them have the highest IV level of accreditation. Students get a pedagogical education.

\section{INTRODUCTION}

The Faculty of Biology and Ecology was founded in 1918 simultaneously with the University. Prominent scientists worked at the Faculty in different times: P. P. Shirshov, G. B. Mel'nikov, M. P. Akimov, L. V. Reingard, O. L. Bel'gard, V. M. Arkhangel'sky, G. I. Galazij, O. D. Reva, P. E. Motcnyi, D. O. Lubyanov and many others. In 2009 year the Medicine department was joined and the Faculty of Biology and Ecology got a new name - The Biology, Ecology and Medicine Faculty.

The Faculty of Biology, Ecology and Medicine has 7 Departments, Aquarium complex, Zoological Museum, Vivarium and Herbarium. It works in cooperation with the Research Institute of Biology, Botanical Garden, O. L. Bel'gard International Biosphere Station, and Biological Station of DNU and forms the regional Centre of Science, Education and Culture in the field of Biology, Ecology and Nature Conservation in Central Ukraine. The Faculty proposes courses in the following specialties: Biology, Zoology, Botany, Microbiology and Virology, Biochemistry, Physiology, Ecology, Environmental Protection and Balanced Nature Management. All of them have the highest IV level of accreditation. Students get a pedagogical education.

The Biology, Ecology and Medicine Faculty offers an internal and external studies and instruction by correspondence. It trains Bachelors (License), Specialists and Masters in Biology, Ecology and Medicine. We have post-graduate courses and specialized Academic council in Ecology. The key personnel are involved in high level research of several scientific schools.

Consider some description of the Biology, Ecology and Medicine Faculty of DNU main directions.

\section{Chair of Geobotany, Soil science and Ecology.}

The G. M. Visotz'kiy, O. L. Bel'gard science school is successfully developing owing to Corresponding Member of NAS Ukraine, Doctor of Biological Science, Honoured Worker of Science and Engineering of Ukraine, Professor A. P. Travleev. His staff solves many problems of steppe dendrology; the last one is a theoretical basis of steppe forestry and forest revegetation of Ukraine's soils. Science school main workings: the steppe forests typology, the steppe forests and soils interaction, the forest chernozems and its micromorphology, the permanent biogeocoenology, the forest phytocoenosis dynamics and structure, the microbecoenosis and its functioning, the artificial soils and forests construction on colliery's dumps.

During the 52 years there Complex Expedition of steppe forests ecology investigates the Dnipropetrovs' $\mathrm{k}$ region, and Prisamarskyi scientific biosphere permanent establishment of DNU, which got the international status as Ecological Cadres Training Centre in the South of Ukraine.

\section{Chair of Radiobiology and Freshwater Radioecology.}

There is a science school under the direction of academician Ukraine Ecological Academy of Science, Honoured Worker of Science and Engineering of Ukraine, Professor A. I. Dvoretskiy in here. Theoretical researching and practical recommendations concerning the substantiation of technogenic pressing level of ponds of middle Dnieper, and minimization measures of anthropogenic factors adverse effect for alive organisms, are recognized by scientists not only of Ukraine but and other countries all over the word. 


\section{Chair of Molecular biology and Plant physiology.}

The theoretical foundation of the science school became by the investigations of Professors A. V. Reingard and O. M. Michailov. It leads by the Honoured Worker of Science and Engineering of Ukraine, Professor O. M. Vinnychenko. Theoretical workings on establishment of detrimental effect of various nature factors complex pattern to plant ecosystems, a lot of workings of removal their negative influence methods and the complex realization of mutant genes in plant organisms obtained big public recognition.

\section{Chair of Physiology and Biochemistry of microorganisms.}

The science base school was placed by Doctors of Biological Science, Professors U. S. Babenko and Ye. I. Demichovs'kiy. Theoretical researching of biochemical and genetic mechanisms of organisms stability to antibiotics and also some problems of genetic information transferring in bacteria, pathogenesis of urogenital infections, which are carried out of Ukraine's Higher School academician, Honoured Worker of Science and Engineering of Ukraine, Professor A. I. Vinnykov have the priority importance for microbiology and molecular biology development.

Science results of complex litical enzymatic preparation of actinomycete study, new types of bioinsecticides are found out the application in different fields of national economy.

\section{Chair of Hydrobiology and Ichthyology.}

Investigations of hydro-biologists and ichthyologists science school, which was obtained in 1928 year by the Corresponding Member of NAS Ukraine, Professor D. O. Svirenko, is continued by his progeny and followers Professors G. B. Mel'nikhov, P. O. Gzuravel', I. P. Lubianov, S. P. Fediy, A. I. Dvoretskiy. By solving problems of clean water scientists determine ecological and toxicological condition of Pridniprovia's ponds, its bioproduction.

On the basis of theoretical workings new technologies of fish growing are inculcated in artificial reservoirs.

\section{Chair of Zoology and Ecology.}

The science school foundation is zoological and ecological base, which was obtained by zoologists, Professors L. V. Reingard and V. V. Stahovs'kiy and formed by Professor V. L. Bulakhov, is successfully developing now owing to the Corresponding Member of NAS Ukraine, academician Ukraine Ecological Academy of Science, Honoured Worker of Science and Engineering of Ukraine, Professor O. Ye. Pakhomov. Priority science directions are - the researching of animal population's structure and functional role in multifarious nature and transformed systems.

For the first time was mounted the zoocenosis adaptation on different levels its organization to technogenic factors. Also it was determined some regularity of environment formative animal action in ecosystem biogeocoenotic processes and homeostasis mechanism forming.

A few add information about the Chair of Zoology and Ecology.

Stuff of this chair is intensively engaging in ecology major and relevant problems. On the basis of zoological sciences owing to active development of ecological investigations in 1991 year the chair of Zoology and Ecology was organized, where in harmonious tandem both sciences started to consider.

The chair prepare Bachelor of «Biology» direction, Specialists and Masters of the following specialties: «Zoology» (the specialization is «Ecology and Biodesign») and «Ecology, Environment preservation and Balanced nature use» (the specialization is «Ecological audit»). Here students get knowledge on humanitarian, natural, pedagogical and biological disciplines from philosophy and economy to ecology, biodesign and psychology.

Students getting their science skills on the O. L. Bel'gard International Biosphere Station, and Biological Station of DNU, Research Institute of Biology, Botanical Garden, Dniprovsko-Orilskiy reserve, Hunting and Forestry economy, on different industrial enterprises, at management and State Administration offices, Ecological safety Ministry etc.

The chair has Zoological museum and vivarium. It is significant that museum is great base for popularization of nature preserve ideas and also for working up the practical recommendations of animal world preserve and its rational use; animal in reserves, hunting economies, botanical gardens, parks. Zoological museum acquaints with animal role in ecological balance preservation in nature, animal world organization features in conditions of hard ecological situation, and the main is opportunity to see a beauty and affinity of animal planet.

The chair of Zoology and Ecology gives a postgraduate education and a raising the level of official skill of industry, agriculture and education. The chair fruitfully cooperates with Ecological Naturalistic Centre, Junior Science Academy. 
Primary directions of the chair of Zoology and Ecology science work are:

1. The investigation of zoogenic mechanisms of soils remediation and ecosystems recultivation in technogenic strained pressure condition.

2. The anthropogenic dynamics of zoocenosis researching, preservation prospects, optimization and nature rational use.

3. The study of animal functional role in ecosystems.

4. The working up of ecology and biochemistry estimation of faunas state under the technogen factors influence.

5. The inventory and ecological estimation of Dnipropetrovsk region nature fond and the creation of geoinformative system apply.

Our graduators work in research institutes, educational establishments, committees and ministry of nature protection and nuclear safety, food, microbiological, biochemical and biotechnological industries, problem laboratories, nature reserves, centers of career-guidance, botanical gardens, plants protection stations, organizations of land restoration and laying out of parks, agriculture, hunting and fish industry, environmental police, sport organizations and medical establishments.

The Biology, Ecology and Medicine Faculty stuff profitably cooperates with foreign scientific centers and educational establishments of Russia, Greece, China, Bulgaria, France, Italy, The Netherlands, Czechia, Romania, Belgium, Great Britain, Germany, Poland, USA, Israel, Sweden, etc. Tightly business connections are with colleges from Russia, Byelorussia, and Baltic. Researches of Dnipropetrovs'k National University organize International Conferences, Symposiums, etc. Collaborates and students get grants for further investigations, international; trainings, etc.

\section{REFERENCES}

http://www.dsu.dp.ua/

Історія Дніпропетровського національного університету / Голова редколегії проф. М. В. Поляков. - 4-те вид., переробл. і доповн. Д. : Вид-во ДНУ, 2008. - 308 с.

Професори Дніпропетровського національного університету імені Олеся Гончара: Біобібліограф. довідник / Голова редкол. проф. М. В. Поляков. - 2-е вид., перероб. і доп. - Д. : Вид-во Дніпропетр. нац. ун-ту, 2008. - 596 с.

Ми - з класичного університету. Дніпропетровський національний: час, події, люди // За заг. редакцією проф. М. В. Полякова. - 2 ге видання, доповнене, перероблене. - Д. : Вид-во Дніпропетр. нац. ун-ту. - 2008. - 148 с. 